\title{
On-farm establishment of drought-tolerant pastures on the east coast of the North Island
}

\author{
D. R. SMITH', M. W. A. SLAY', M. H. GRAY' and G. D. MILNE \\ 'AgResearch, Poukawa Research Station, PO Box 8144, Havelock North \\ ${ }^{2}$ AgResearch, Grasslands Research Centre, PB 11008, Palmerston North
}

\begin{abstract}
Seedling and tiller core measurements on 60 paddocks sown in autumn 1991 on the East Coast of the North Island were made to monitor the success of new pastures based on drought-tolerant grasses. Pastures sown into cultivated seedbeds were generally more successful than direct-drilled pastures, having higher content of sown species and less competition from volunteer perennial grasses. In paddocks sown with mixtures of tall fescue and Grasslands Wana cocksfoot, cocksfoot was becoming the dominant grass, except in areas of paddocks with poor drainage. Cocksfoot establishment in oversown pastures was good, but tall fescue in these paddocks declined to low levels 19 months after sowing. White clover was well established in all classes of pasture, despite relatively low initial seedling numbers in direct drilled and oversown paddocks. In contrast, red clover content declined, particularly in directdrilled and oversown paddocks.
\end{abstract}

Keywords: Dactylis glomerata, direct drilling, Festuca arundinacea, pasture establishment, Phalaris aquatica, oversowing

\section{Introduction}

Improved cultivars of cocksfoot, tall fescue and phalaris have been widely promoted for dryland pastures as alternatives to perennial ryegrass. Guidelines for establishment and management of these grasses have been developed (Hume Fraser 1985), but have not always been put into practice on the farm. As part of the 1990191 East Coast Drought Recovery assistance programme, pastures based on drought-tolerant grasses were sown in autumn 1991 on farms in the east coast districts of the North Island. Grassline consultants provided detailed guidelines on seed mixtures, establishment and management of these pastures. Sixty of these paddocks in the Gisborne and Hawkes Bay regions were selected for monitoring to measure establishment success and to identify factors contributing to the persistence of sown species.

\section{Methods}

The 60 paddocks selected included 31 established by drilling into a cultivated seedbed, 17 by direct-drilling and 12 by oversowing (Milne et al. 1993). Details of paddock history, sowing operations and perceptions on establishment success were obtained from questionnaires completed by farmers.

Cultivated paddocks were sown either with a roller drill (27 paddocks) or by using a conventional drill with the coulters removed. Nineteen of the cultivated paddocks were established following a crop. All but two of the direct-drilled paddocks sampled had undergone a spray fallow programme (sprayed with herbicide in early summer and again before sowing), the two exceptions being sprayed only once before sowing. All oversown paddocks were sprayed at least once with herbicide prior to sowing, with one paddock being sprayed twice.

Paddocks ranged in size from 1 to 25 ha. Cultivated and direct-drilled paddocks averaged 7 ha and oversown paddocks averaged 12 ha. Mean annual rainfall on the farms surveyed ranged from 750 to $1600 \mathrm{~mm}$, with an average of $1150 \mathrm{~mm}$.

Most paddocks had tall fescue (Festuca arundinacea), cocksfoot (Dactylis glomerata), or both in the seed mix. Grasslands Roa tall fescue was in 29 seed mixes, Au Triumph tall fescue in 15, Grasslands Wana cocksfoot in 40 and Grasslands Kara cocksfoot in 15. Other sown grasses were Grasslands Maru phalaris (Phalaris aquatica) in 31 seed mixes and Grasslands Gala grazing brome (Bromus stamineus) in 4. Grasslands Puna chicory (Cichorium intybus) was included in 13 seed mixes. White clover (Trifolium repens) cultivars used were Grasslands Tahora (39 seed mixes), Grasslands Kopu (19), Grasslands Pitau (1 1), and Grasslands Huia (1). Red clover ( $T$. pratense) cultivars used were Grasslands Colenso (27 seed mixes) and Grasslands Pawera (9).

Seedling populations of sown species were measured in June 1991. Paddocks were examined and divided into 4 sampling areas, or "quarters". Each quarter was scored visually for slope class $\left(0-100,10-30^{\circ},>30^{\circ}\right)$, predominant aspect, and texture of the topsoil (on a scale of 1 to 5 , with 1 indicating sand to 5 indicating heavy clay). Seedling emergence of sown species and 
of volunteer perennial ryegrass (Lolium perenne) was estimated from plant counts in $150 \mathrm{~mm}$ x $300 \mathrm{~mm}$ quadrats, with 15 quadrats per quarter. Seed depth was estimated from sown grass seedlings dug up at 8 sites per quarter.

In November 1991 and November 1992, the paddocks were revisited and the original quarters identified and visually scored for cover and plant vigour. In addition, the areas were sampled using a tiller core technique (Mitchell \& Glenday 1958) to measure pasture composition. Twenty-five soil cores, each $50 \mathrm{~mm}$ in diameter, were collected from each of the four quarters, returned to the laboratory, and scored for the presence of sown grasses and legumes as well as other species (other perennial grasses, annual grasses, annual legumes, flatweeds). Perennial ryegrass and browntop (Agrostis capillaris) were scored separately from other volunteer perennial grass species.

Stepwise regression analysis was used for exploratory data analysis, with seedling and tiller core data as dependent variables, and variables describing seed rates, paddock history, slope, aspect, soil texture and drainage as potential predictors. The four quarters of each paddock were treated as separate experimental units to allow analysis of within-paddock variation in species composition. The regression analyses were done separately for each sowing method (cultivated, directdrilled, oversown) and for each sown species, using data from only those paddocks in which the species was included in the seed mix. Sowing rates were forced in as covariates at the start of the stepwise procedure. The results presented here include a descriptive comparison of measurements made in paddocks sown by different methods and analyses of three factors seed mixture, drainage and aspect - which have been consistently selected by the stepwise regression algorithm as being strongly associated with establishment success in tall fescue/cocksfoot mixtures. Tests of significance that are presented for these analyses should be treated with caution, since they have been suggested by the data rather than by a priori hypotheses.

\section{Results and discussion}

Of the 60 paddocks surveyed, 3 were sown in February, 26 in March, 30 in April and 1 in May. Rainfall in autumn 1991 was higher than average for most farms in the survey. On average, $96 \mathrm{~mm}$ fell in the first 2 weeks after sowing of the survey paddocks and $66 \mathrm{~mm}$ fell in the following 2 weeks.

Differences between sowing methods

When asked 3 months after sowing to rate the establishment of sown grasses, most farmers considered the sowing to be successful (Table 1). The responses to this question indicated no differences between grasses in perceived establishment success, suggesting that farmers were appraising the overall grass content of the new pasture, rather than individual species. Greatest success was perceived for paddocks sown into cultivated seedbeds.

Table 1 Number of paddocks rated as poor, fair or good by farmers 3 months after sowing. Values in parentheses are percentages calculated on a row (sowing method) basis.

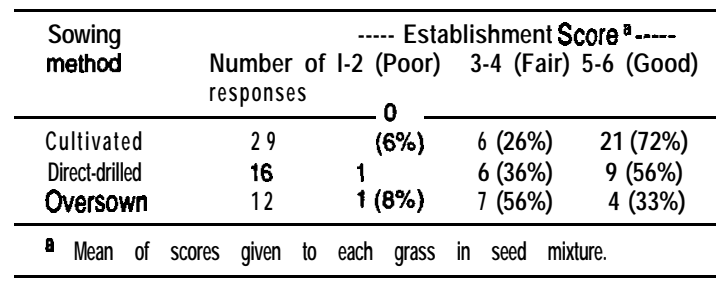

Grass seed depth in paddocks sown into cultivated seedbed was generally within the recommended range of 10-15 mm (Hume \& Fraser 1985) and averaged 11 $\mathrm{mm}$, while seed depth in paddocks sown by direct drilling averaged $26 \mathrm{~mm}$. Seed depth in oversown paddocks showed the greatest variability, ranging from 0 to $12 \mathrm{~mm}$ and averaging $5 \mathrm{~mm}$.

Results of seedling counts indicated that numbers of sown grass plants were greatest in cultivated paddocks and lowest in oversown paddocks (Table 2). These differences between sowing method have generally been maintained in tiller core measurements made over the following two springs.

Cocksfoot content tended to increase in cultivated paddocks (from 33 to $45 \%$ ) and direct-drilled paddocks (from 24 to 33\%) from the first to second spring after sowing. This increase in cocksfoot content is consistent with earlier survey work of east coast North Island pastures, which showed that cocksfoot content increased during the first 3 to 4 years after sowing (Korte et al. 1991). Cocksfoot content in oversown paddocks was relatively constant from spring 1991 to spring 1992 at about $30 \%$. Although cocksfoot presence in oversown paddocks has been similar to that in direct-drilled and cultivated paddocks, this has been at the expense of relatively high sowing rates. The mean sowing rate of $12 \mathrm{~kg} / \mathrm{ha}$ equates to approximately $1700 \mathrm{seed} / \mathrm{m}^{2}$; less than $10 \%$ of these seed had established by 3 months after sowing.

Tall fescue content remained relatively constant in cultivated paddocks (averaging $3 \quad 1 \%$ ) and direct-drilled paddocks $(25 \%)$. Where it was included in seed mixtures 
Table 2 Mean seed rates, seedling numbers in winter after sowing and occupancy of tiller cores in first and second spring after sowing for main grass species. Standard deviation of paddock means given in parenthesis.

\begin{tabular}{|c|c|c|c|c|c|}
\hline \multirow[t]{2}{*}{ Sowing method and species } & \multirow{2}{*}{$\begin{array}{l}\text { Number of } \\
\text { paddocks }\end{array}$} & \multirow{2}{*}{$\begin{array}{l}\text { Mean seed rate } \\
\quad(\mathrm{kg} / \mathrm{ha})\end{array}$} & \multirow{2}{*}{$\begin{array}{l}\text { Seedlings } \\
\text { June } 1991 \\
\text { (plants/m²) }\end{array}$} & \multicolumn{2}{|c|}{ Occupancy of cores $(\%)$} \\
\hline & & & & Spring 1991 & Spring 1992 \\
\hline \multicolumn{6}{|l|}{ Cultivated ( $n=31)$} \\
\hline Tall fescue & 25 & 17 & $221 \quad(89)$ & $31(15)$ & \multirow{3}{*}{$\begin{array}{cc}31 & (20) \\
45 & (22) \\
5(6)\end{array}$} \\
\hline Cocksfoot & 26 & 4.9 & $163(114)$ & $33(16)$ & \\
\hline Phalaris & 13 & 2.2 & $46(16)$ & $4(3)$ & \\
\hline \multicolumn{6}{|l|}{ Direct drilled $(n=17)$} \\
\hline Tall fescue & 15 & 17 & $174 \quad(65)$ & $26(10)$ & \multirow{2}{*}{$\begin{array}{l}24(13) \\
34(14)\end{array}$} \\
\hline Cocksfoot & 14 & 4.4 & 79 (28) & $24(10)$ & \\
\hline Phalaris & 6 & 2.0 & $33(13)$ & $3(2)$ & $4(2)$ \\
\hline \multicolumn{6}{|l|}{ Oversown (n=12) } \\
\hline Tall fescue & 4 & 10 & $54(26)$ & \multirow{3}{*}{$\begin{array}{c}17(9) \\
30(10) \\
2(2)\end{array}$} & \multirow{3}{*}{$\begin{array}{c}\mathbf{5}(4) \\
32(15) \\
\mathbf{1}(2)\end{array}$} \\
\hline Cocksfoot & 12 & 12 & $127 \quad(60)$ & & \\
\hline Phalaris & 12 & 4.6 & $23(13)$ & & \\
\hline
\end{tabular}

Table 3 Mean seed rates, seedling numbers in winter after sowing and occupancy of tiller cores in first and second spring after sowing for main sown legumes. Standard deviation of paddock means given in parenthesis.

\begin{tabular}{|c|c|c|c|c|c|}
\hline \multirow[t]{2}{*}{ Sowing method and species } & \multirow{2}{*}{$\begin{array}{l}\text { Number of } \\
\text { paddocks }\end{array}$} & \multirow{2}{*}{$\begin{array}{l}\text { Mean seed rate } \\
(\mathbf{k g} / \mathrm{ha})\end{array}$} & \multirow{2}{*}{$\begin{array}{l}\text { Seedlings } \\
\text { June } 1991 \\
\text { (plants/m²) }\end{array}$} & \multicolumn{2}{|c|}{ Occupancy of cores $(\%)$} \\
\hline & & & & Spring 1991 & Spring 1992 \\
\hline \multicolumn{6}{|l|}{ Cultivated $(n=31)$} \\
\hline White clover & 31 & 2.8 & $172(82)$ & $52(17)$ & $67(18)$ \\
\hline Red Clover & 20 & 3.8 & $71(29)$ & $14(8)$ & $8(3)$ \\
\hline Sub clover & 2 & 5.0 & $29(5)$ & $3(1)$ & $1(1)$ \\
\hline \multicolumn{6}{|l|}{ Direct drilled $(n=17)$} \\
\hline White clover & 17 & 2.8 & $60(76)$ & $45(16)$ & $60(14)$ \\
\hline Red clover & 10 & 3.9 & 42 (22) & $8(5)$ & $2(2)$ \\
\hline Sub clover & 1 & 5.0 & 33 & 46 & 22 \\
\hline \multicolumn{6}{|l|}{ Oversown $(n=12)$} \\
\hline White clover & 12 & 4.8 & $99(62)$ & 44 (22) & $52(18)$ \\
\hline Red clover & 5 & 4.8 & $47 \quad(32)$ & $8(6)$ & $3(4)$ \\
\hline Sub clover & 8 & 5.8 & $18(11)$ & $10(6)$ & 11 (13) \\
\hline
\end{tabular}

for oversown paddocks, it has declined from $17 \%$ to $5 \%$.

Phalaris, where sown, has remained a minor component of the sward, averaging about $4 \%$ occupancy of cores 19 months after sowing.

Although seedling establishment of white clover was initially much higher in cultivated paddocks than in direct-drilled ō ōvērsō̄̄ $\bar{n}$ paddocks, the differences between sowing methods were small by the first spring after sowing (Table 3 ). The rapid recovery of white clover in oversown and direct-drilled paddocks probably reflects the contribution of buried seed and regeneration from resident white clover stolons. Red clover content, as measured by occupancy of tiller cores, has declined to low levels in direct-drilled and oversown paddocks. These results suggest that the useful contribution of red clover in these situations may be limited to the first 2 years after sowing. The sub clover content of oversown paddocks has remained relatively stable over the two spring measurements, averaging about $10 \%$ occupancy of tiller cores, in paddocks where it was sown. For comparison, sub clover has averaged about $5 \%$ in oversown survey paddocks where it was not included in the seed mixture.

Occupancy of cores by broadleaf weeds declined from spring 1991 (averaging 20\% of cores) to spring $1992(1 \%)$ in both cultivated and direct-drilled paddocks. In contrast, broadleaf weeds have remained at about $20 \%$ occupancy of cores in oversown paddocks.

Competition from unsown grass species increased from spring 1991 to spring 1992. Cultivated paddocks had the least amount of contamination from volunteer perennial ryegrass (averaging 13\% occupancy of cores by spring 1992). browntop (13\% of cores), and other perennial grasses (20\% of cores). Perennial ryegrass and annual grasses were most invasive in oversown paddocks, reaching average levels of $31 \%$ and $13 \%$ of cores, respectively, by spring 1992. Browntop and other 
low fertility perennial grasses showed greatest increases in direct-drilled paddocks $(22 \%$ and $36 \%$, respectively, by spring 1992). The relatively deep placement of seed in direct-drilled paddocks probably contributed to the reduced seedling establishment in these paddocks compared with cultivated paddocks. In addition the effect of excessive seed depth on reducing seedling vigour (Woodman et al. 1990) would also render the seedlings more sensitive to competition from volunteer species and contribute to lower sown grass content in subsequent tiller core measurements.

\section{Seed mixture effects}

In paddocks sown with mixtures of tall fescue and cocksfoot, the result has been a gradual increase in the dominance of cocksfoot. In cultivated and direct-drilled paddocks sown with both tall fescue and cocksfoot, the ratio of tall fescue to cocksfoot seedlings in the first winter averaged about 2:1 (unpublished data). By 7 months after sowing the ratio of tall fescue to cocksfoot in tiller cores averaged 1:1. By 19 months after sowing, the ratio averaged $2: 3$.

In cultivated and direct-drilled paddocks, the content of volunteer ryegrass, browntop and other volunteer perennial grasses was less when Wana cocksfoot was included in the seed mixture with tall fescue than when Wana was not in the mixture (Table 4). This trend was not observed in Kara/tall fescue mixtures. Kara cocksfoot tended to be less dominant over tall fescue than Wana. However, this was due to reduced presence of cocksfoot rather than to increased presence of tall fescue. There was no evidence that Wana cocksfoot was suppressing white clover at this stage. Oversown paddocks sown with a high rate of Wana cocksfoot had lower ryegrass content (23\% ryegrass in cores in November 1992)) than paddocks sown with tall fescue/ cocksfoot mixtures (49\% ryegrass).
The ability of Wana cocksfoot to increase (in directdrilled and cultivated paddocks) or remain stable (in oversown paddocks) in the face of competition from other species confirms the suitability of Wana cocksfoot for the more difficult dryland environments.

\section{Drainage}

The general dominance of cocksfoot over tall fescue in mixtures was reduced in areas of impeded drainage, especially in cultivated paddecks (Table 5). The tolerance of tall fescue to poor drainage, particularly in winter, has long been recognised (Cowan 1956). However, the high levels of low fertility grasses (mainly browntop and Yorkshire fog) invading these areas, particularly in direct-drilled paddocks, may jeopardise the long-term persistence of tall fescue unless fertility is maintained. The high ratio of volunteer grasses to cocksfoot in poorly drained areas suggests that the competitiveness of cocksfoot towards other grasses was also reduced by poor drainage conditions.

\section{Aspect}

In cultivated paddocks, a reduction in cocksfoot dominance over tall fescue was noted on southerly faces compared with northerly (Table 6). In directdrilled paddocks as in cultivated paddocks, initial seedling emergence was enhanced on southerly aspects. However, in direct-drilled, no effect of aspect on sown species was observed in later tiller core measurements. The high presence of other perennial grasses on southerly aspects in direct-drilled paddocks again suggests reduced relative competitiveness of cocksfoot in these situations. These results also suggest that tall fescue's' potential is most likely to be realised following cultivation to reduce competition from other perennial grasses during establishment

Table 4 Effects of cockffoot cultivar on establishment of tall fescue, volunteer species and white clover in cultivated paddocks.

\begin{tabular}{|c|c|c|c|c|c|c|c|c|c|}
\hline \multirow[t]{2}{*}{ Seed Mixture } & \multicolumn{2}{|c|}{$\begin{array}{l}\text { Seedlings } / \mathrm{m}^{*} \\
\ldots-(\text { (June 1991) }\end{array}$} & \multicolumn{7}{|c|}{ \% Occupancy of cores } \\
\hline & CFa & TF & CF & TF & RG & BT & OPG & FW & WC \\
\hline Wana+Tall fescue & 115 & 172 & 54 & 25 & 8 & 8 & 10 & 5 & 75 \\
\hline Kara+Tall fescue & 98 & 206 & 23 & 31 & 21 & 20 & 26 & 15 & 61 \\
\hline Tall fescue alone & 0 & 255 & 0 & $\begin{array}{l}55 \\
\ddagger \ddagger\end{array}$ & $\begin{array}{l}10 \\
\ddagger\end{array}$ & 2 & $\begin{array}{l}47 \\
\ddagger \ddagger \ddagger\end{array}$ & 13 & 59 \\
\hline
\end{tabular}

a $C F=$ cocksfoot, $T F=$ tall fescue, $R G=$ yyegrass, $B T=$ browntop, OPG=other perennial grasses, $F W=f l a t w e e d s$, WC $=$ white clover.

Contrast between Wana and Kara cocksfoot significant at $P=0.05,0.01,0.001$ respectively, after covariate adjustment for cocksfoot and tall fescue seed rates.

$\ddagger . \ddagger \ddagger . \ddagger \ddagger \quad$ Contrast between Cocksfoot+Tall fescue vs. Tall fescue alone significant at $P=0.05,0.01,0.001$, respectively, after covarlate adiustment for cocksfoot and tall fescue seed rates. 
Table 5 Consequences of drainage on establishment of sown and volunteer grass species in tall fescue/cocksfoot paddocks.

\begin{tabular}{|c|c|c|c|c|c|c|c|}
\hline \multirow[t]{2}{*}{$\begin{array}{l}\text { Sowing method } \\
\text { and drainage }\end{array}$} & \multicolumn{2}{|c|}{$\begin{array}{c}\text { Soedlings/m}{ }^{2} \\
\ldots . \text { (June 1991) }\end{array}$} & \multicolumn{5}{|c|}{ \% Occupancy of cores } \\
\hline & $\mathrm{CF}^{\mathrm{a}}$ & $\pi F$ & CF & TF & RG & BT & OPG \\
\hline \multicolumn{8}{|l|}{ Cultivated } \\
\hline Poor drainage & 99 & 200 & 30 & 35 & 16 & 20 & 29 \\
\hline Good drainage & 111 & 170 & 44 & 25 & 12 & 11 & 12 \\
\hline \multicolumn{8}{|l|}{ Direct-Drilled } \\
\hline Poor drainage & 57 & 153 & 25 & 22 & 21 & 26 & 40 \\
\hline Good drainage & 69 & 155 & 36 & 24 & 14 & 16 & 31 \\
\hline
\end{tabular}

a $\quad \mathrm{CF}=$ cockstoot, $\mathrm{TF}=$ tall fescue, $\mathrm{RG}=$ ryegrass, $\mathrm{BT}=$ browntop, $\mathrm{OPG}=$ other perennial grasses

..${ }^{*}$, ** Contrast between poor and good drainage significant at $P=0.05,0.01,0.001$ respectively, after covariate adjustment for seed rates of cocksfoot and tall fescue.

Table 6 Consequences of northerly and southerly aspects on establishment of sown and volunteer species in tall fescue/co\&foot paddocks.

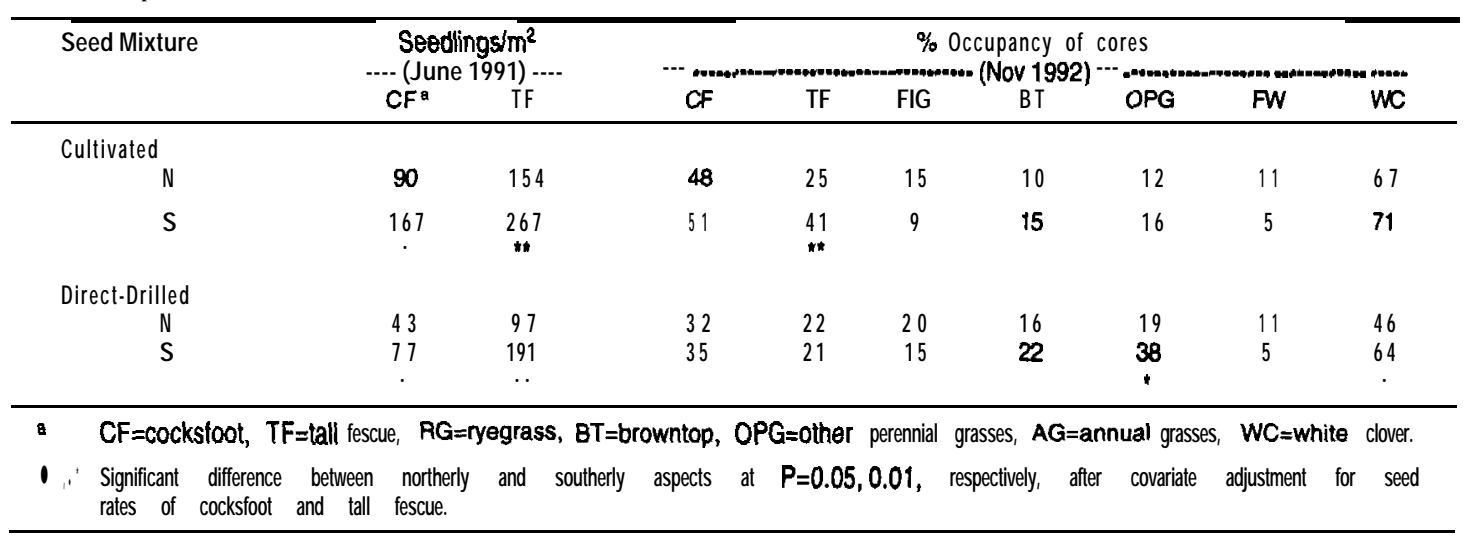

\section{Conclusions}

When provided with detailed technical advice on pasture establishment and management, most farmers were satisfied with the initial performance of dryland pasture species.

A strong cocksfoot component can be reliably achieved in new pastures established in hill country as well as tillable land.

Excessive seed depth was possibly a problem in direct-drilled paddocks.

In the early stages of establishment, Wana cocksfoot was more competitive against volunteer ryegrass and low fertility grasses than was tall fescue. This is particularly important in direct-drilled and oversown hill country situations where fertiliser and other management inputs arc limited. Survival of tall fescue was very poor when oversown into hill country.

Increasing dominance of the cocksfoot component in mixed cocksfoot/tall fescue pasture by the cocksfoot component suggests that cost of including tall fescue in a "general purpose" seed mixtures may not be justified unless a paddock presents specific problems (e.g., poor drainage). Tall fescue was most successful when sown as the sole grass after cultivation. Control or elimination of resident perennial grasses before sowing and high paddock fertility should be achieved to ensure tall fescue competitiveness.

\section{REFERENCES}

Cowan, J.R. 1956. Tall fescue. Advances in agronomy 8: 283-320.

Hume, D.E.; Fraser, T.J. 1985. Establishing and managing recent cultivars in arable dryland pastures. In: Burgess, R.E.; Brock, J.L. editors. Using herbage cultivars. Grasslands Research and Practice Series No. 3. New Zealand Grasslands Association, Palmerston North. pp. 45-48. 
Korte, C.J.; Smith, D.; Slay, M.W.A.; Gray, M.; Quilter, S.J. 1991. Preliminary report on a survey of performance of drought tolerant pastures on East Coast sheep/beef farms. MAF Internal Report.

Mitchell,K.J.; Glenday,A.C. 1958. The tiller population of pastures. New Zealand journal of agricultural research 3: 305-318.

Milne, G.D.; Moloney, S.C; Smith, D.R. 1993. Demonstration of dryland pasture species on 90 east coast farms. Proceedings of the New Zealand Grassland Association 55: (this volume).

Woodman, R.F.; Doney, R.J.; Allan, B.E. 1990. Effects of drilling depth on seedling growth of seven dryland pasture species. Proceedings of the New Zealand Grassland Association 52: 167- 170. 